\title{
PENERAPAN PENDEKATAN SAINTIFIK UNTUK MENINGKATKAN KEMAMPUAN KOMUNIKASI MATEMATIK PESERTA DIDIK DI SEKOLAH DASAR
}

\author{
Oleh: \\ Fadhilaturrahmi ${ }^{1}$ \\ Universitas Pahlawan Tuanku Tambusai ${ }^{1}$
}

\begin{abstract}
This study aims to improve the ability of mathematical communication by applying scientific approach in primary school. This study is a classroom action research. The subject of this research is all students of grade $V$ of SD 016 Bangkinang Kota. The instrument used in data collection is a mathematical communication test of the description form. Implementation of learning carried out with 5 steps scientific approach that is: observing, asking, reasoning, try and communicate. This research data obtained from the results by using tests, observations, interviews, and discussions. This research was conducted for two cycles, ie cycle I held two meetings $(6 \times 35$ minutes) and cycle II was held in two meetings (6x 35 minutes). Result of research from every cycle that have been implemented seen improvement. This can be seen in the first cycle, the average value of students' communication skills is $92.61 \%$ percentage of students, and the meeting 2 percentage $62.54 \%$. In the second cycle of meeting 1 , the average value of mathematical communication ability is 8.71 with the percentage of $86 \%$ of students and on the second cycle of meeting 2, the average score of students' mathematical communication ability is 85 with the percentage of 97.20 students. Based on the observations made also seen the increase of student activeness in the learning process. Thus it can be concluded that the research by using scientific approach can improve students' mathematical communication skills
\end{abstract}

Keyword: Saintific approach, mathematics of communication

Abstrak: Penelitian ini bertujuan untuk meningkatkan kemampuan komunikasi matematik dengan menerapkan pendekatan saintifik di sekolah dasar. Penelitian ini merupakan penelitian tindakan kelas. Subjek penelitian ini adalah seluruh siswa kelas V Sekolah dasar 016 Bangkinang Kota. Instrumen yang digunakan dalam pengumpulan data adalah tes komunikasi matematik bentuk uraian. Pelaksanaan pembelajaran dilaksanakan dengan 5 langkah pendekatan saintifik yaitu: mengamati, menanya, menalar, mencoba dan mengkomunikasikan. Data penelitian ini diperoleh dari hasil dengan menggunakan tes, observasi, wawancara, dan diskusi. Penelitian ini dilaksanakan selama dua siklus, yaitu siklus I dilaksanakan dua kali pertemuan (6 x 35 menit) dan siklus II dilaksanakan dalam dua kali pertemuan (6 x 35 menit). Hasil penelitian dari setiap siklus yang telah dilaksanakan terlihat adanya peningkatan. Hal ini dapat dilihat pada siklus I, nilai rata-rata kemampuan komunikasi siswa adalah persentase 92,61\% siswa,dan pertemuan 2 persentasenya $62,54 \%$. Pada siklus II pertemuan 1, nilai rata-rata kemampuan komunikasi matematik adalah 8,71 dengan persentase $86 \%$ siswa dan pada siklus II pertemuan 2, nilai rata-rata kemampuan komunikasi matematik siswa adalah 85 dengan persentase 97,20 siswa. Berdasarkan pengamatan yang dilakukan terlihat juga adanya peningkatan keaktifan siswa dalam proses pembelajaran. Dengan demikian dapat disimpulkan bahwa pada penelitian dengan menggunakan pendekatan saintifik dapat meningkatkan kemampuan komunikasi matematik siswa.

Kata Kunci: Pendekatan saintifik, Kemampuan Komunikasi Matematik

${ }^{1}$ Universitas Pahlawan Tuanku Tambusai, Email: arkhan88fadhila@gmail.com 


\section{PENDAHULUAN}

Kemampuan komunikasi
matematik merupakan salah satu kemampuan yang sangat diharapkan ada pada peserta didik setelah peserta didik belajar matematika. Kemampuan komunikasi matematis diperlukan sejak dini melalui pembelajaran di kelas agar peserta didik bisa memecahkan masalah dan mengaplikasikan konsep matematika sebagai bekal hidup peserta didik masa sekarang dan masa yang akan datang. Sejalan dengan Standar Proses yang disampaikan oleh The National Council of Teachers of Mathematics (Yuniawatika, 2011) yang menetapkan bahwa terdapat 5 kemampuan yang perlu dimiliki peserta didik melalui pembelajaran matematika yang tercakup dalam standar proses dimana salah satunya adalah kemampuan komunikasi matematik.

Hasil observasi di lapangan yakni di SDN 016 Bangkinang Kota terkait kemampuan komunikasi ini sebenarnya guru sudah berupaya untuk meningkatkan kemampuan komunikasi matematik ini, dan kemampuan ini juga sudah ada pada peserta didik, namun belum berkembang dengan baik. Dalam hal komunikasi yang dilihat secara tulisan, tampak bahwa dari hasil penyelesaian soal dari peserta didik, yang membutuhkan penjelasan tampak peserta didik belum maksimal mengungkapkan ekspresi atau gagasan matematisnya secara baik. Hasil wawancara yang dilakukan pada guru kelas juga menggambarkan bahwa kemampuan komunikasi matematik ini sangat lemah, peserta didik kurang bisa menjelaskan baik secara lisan maupun tulisan dari penyelesaian soal yang telah diberikan. Guru juga menyampaikan sudah berupaya untuk mengembangkan kemampuan ini, hanya saja mungkin belum menemukan metode yang tepat sehingga belum berkembang dengan baik.

Berdasarkan pada penjabaran di atas, tentang pentingnya mengembangkan kemampuan komunikasi matematik dan melihat pada kesenjangan di lapangan, maka jika kemampuan ini tidak dikembangkan dengan baik, maka tujuan pembelajaran matematika secara tidak langsung juga tidak akan tercapai. Hal ini, akan membawa dampak negatif terhadap pengaplikasian kemampuan matematika tersebut menjadi terhambat pada peserta didik ketika menyelesaikan permasalahanpermasalahan matematika yang menggunakan kemampuan tersebut dalam pemecahannya.

Dari penjabaran masalah diatas, peneliti memberikan salah satu alternatif pembelajaran untuk meningkatkan kemampuan komunikasi matematik ini yakni dengan menerapkan Pendekatan Saintifik. Pendekatan saintifik ini sudah ada sejak dikeluarkannya Kurikulum 2013. Namun implementasinya tidak diterapkan oleh seluruh sekolah terutama di sekolah dasar. Di sekolah tempat penelitian ini masih menggunakan KTSP 2006, sehingga Pendekatan saintifik baru pertama kali diterapkan disana.

Pendekatan saintifik merupakan salah satu pendekatan pembelajaran ilmiah. Majid (2014: 193) mengungkapkan bahwa penerapan pendekatan saintifik bertujuan untuk pemahaman kepada peserta didik dalam mengenal, memahami berbagai materi menggunakan pendekatan ilmiah, bahwa informasi bisa berasal dari mana saja, kapan saja, tidak bergantung pada informasi searah dari guru.

Daryanto (2014: 51) mengungkapkan bahwa pembelajaran dengan pendekatan saintifik adalah proses pembelajaran yang dirancang sedemikian rupa agar peserta didik secara aktif mengkonstruksi konsep, hukum atau prinsip melalui tahapantahapan mengamati, merumuskan masalah, mengajukan atau merumuskan hipotesis, mengumpulkan data dengan berbagai teknik, menganalisis data, menarik kesimpulan dan mengkomunikasikan konsep, hukum atau prinsip yang ditemukan.

Pendapat para ahli di atas dapat disimpulkan bahwa pendekatan saintifik merupakan pendekatan yang berpusat kepada peserta didik agar peserta didik 
secara aktif mengkonstruksi konsep, hukum atau prinsip melalui tahapantahapan mengamati, merumuskan masalah, mengajukan atau merumuskan hipotesis, mengumpulkan data dengan berbagai teknik, menganalisis data, menarik kesimpulan dan mengkomunikasikan konsep, hukum atau prinsip yang ditemukan.

\section{TINJUAN PUSTAKA}

Dalam Curriculum and Evaluation Standards (NCTM, 1989: 6) dinyatakan bahwa salah satu kemampuan dasar berpikir matematika yang diharapkan dimiliki oleh peserta didik yaitu berkomunikasi secara matematika. Cai (Rahmawati, 2013: 232) mengemukakan bahwa "communication is considered as the means by which teachers and students can share the processes of learning, understanding, and doing mathematics". Komunikasi dianggap sebagai alat yang bisa membantu guru dan peserta didik bisa berbagi proses-proses pembelajaran, pemahaman dan mengerjakan matematika.

$$
\text { Rakhmat (Bistari, 2010: 4) }
$$

mengungkapkan bahwa komunikasi menyentuh segala aspek kehidupan manusia. Penelitian menunjukkan bahwa $70 \%$ waktu bangun manusia digunakan untuk berkomunikasi. Dengan komunikasi kita membentuk saling pengertian menumbuhkan persahabatan, memelihara kasih sayang, menyebarkan pengetahuan dan melestarikan peradaban. Terkait dengan peran komunikasi, Hinker\& Laughlin (Bistari, 2010:4) mengungkapkan bahwa salah satu tujuan yang ingin dicapai dalam pembelajaran matematika adalah memberikan kesempatan seluas-luasnya kepada peserta didik untuk mengembangkan dan mengintegrasikan keterampilan berkomunikasi. Banyak cara untuk mengembangkan keterampilan komunikasi tersebut yaitu melalui lisan dan tulisan, modelling, gambar serta mempresentasikan apa yang telah dipelajari.
Dalam Ontario Ministry of Education (Anonim, 2005: 17) juga mengungkapkan tentang pentingnya kemampuan komunikasi, sebagaimana yang dikemukakannya bahwa

Why is mathematical communication important?Mathematical

communication is an essential process for learning mathematics because through communication, students reflect upon, clarify and expand their ideas and understanding of mathematical relationships and mathematical arguments.
Dalam
buku
Connected

Mathematics oleh Lappan 2002 Bistari (2010: 4) juga mengungkap pentingnya komunikasi dalam pembelajaran matematika, 'the overaching goals of connected mathematics is all students should be able to reason and communicate proficiently in mathematics. Untuk menumbuhkembangkan kemampuan komunikasi dalam pembelajaran matematika maka guru harus mengupayakan proses pembelajaran yang optimal, sehingga pembelajaran terjadi secara bermakna. Bistari (2010: 2) juga mengatakan bahwa kemampuan komunikasi matematika memegang peranan penting dalam aktivitas dan penggunaan matematika yang dipelajari peserta didik. Aktivitas yang dimaksud adalah aktivitas peserta didik baik dalam mengkomunikasikan matematika itu sendiri maupun dalam upaya memecahkan masalah yang dihadapi peserta didik dalam matematika atau dalam kehidupan seharihari. Kemampuan komunikasi matematik diperlukan untuk menginformasikan serta memaknai hasil pemecahan masalah yang dilakukan oleh peserta didik.

Komunikasi diperlukan untuk memahami ide-ide matematika secara benar. Kemampuan komunikasi yang lemah akan berakibat pada lemahnya kemampuan-kemampuan matematika yang lain. Peserta didik yang mempunyai komunikasi matematis yang baik akan bisa membuat representasi yang beragam, hal 
ini akan lebih memudahkan dalam menemukan alternatif-alternatif penyelesaian yang berakit pula meningkatnya kemampuan menyelesaikan permasalahan matematika.

Dari pendapat di atas, jelas bahwa komunikasi matematika sangat penting dan merupakan proses yang esensial dalam pembelajaran matematika karena melalui komunikasi peserta didik merenungkan, mengklarifikasi ide-ide serta menghubungkan pemahaman matematik dan argumen matematika.

Mengembangkan kemampuan komunikasi matematis sejalan dengan paradigma baru pembelajaran matematika. Ada paradigma lama, guru lebih dominan dan hanya bersifat mentransfer ilmu pengetahuan kepada peserta didik. Namun, pada paradigma baru pembelajaran matematika, guru merupakan manajer belajar dari masyarakat belajar di dalam kelas, guru mengkondisikan agar peserta didik aktif berkomunikasi dalam belajarnya. Guru membantu peserta didik untuk memahami ide-ide matematis secara benar serta meluruskan pemahaman peserta didik yang kurang tepat (Qahar, 2011).

Kemampuan komunikasi matematis peserta didik bisa dikembangkan dengan berbagai cara, salah satunya dengan menerapkan pembelajaran kooperatif. Hal senanda juga diungkapkan oleh Janvier dalam Bistari (2010: 5), salah satu bentuk aktivitas untuk meningkatkan kemampuan komunikasi yaitu memberikan kesempatan yang seluas-luasnya kepada peserta didik untuk mengembangkan dan mengintegrasikan keterampilan berkomunikasi melalui berbagai representasi, gambar (visual) seperti dalam berdiskusi. Brener (1998) menemukan bahwa pembentukan kelompok-kelompok kecil memudahan pengembangan kemampuan komunikasi matematis. Dengan adanya kelompok-kelompok kecil, maka intensitas seseorang peserta didik dalam mengemukakan pendapatnya akan semakin tinggi. Hal ini akan memberi peluang yang besar bagi peserta didik untuk mengembangkan kemampuan komunikasi matematisnya.

Komunikasi matematis merefleksikan pemahaman matematis dan merupakan bagian dari daya matematis. Peserta didik-peserta didik mempelajari matematika seakan-akan mereka berbicara dan menulis tentang apa yang mereka sedang kerjakan. Mereka dilibatkan secara aktif dalam mengerjakan matematika, ketika mereka diminta untuk memikirkan ide-ide mereka, atau berbicara dan mendengarkan peserta didik lain, dalam berbagi ide, strategi dan solusi. Menulis mengenai matematika mendorong peserta didik untuk merefleksikan pekerjaan mereka dan mengklarifikasi ide-ide untuk mereka sendiri.

Dalam penelitian ini, kemampuan komunikasi matematis akan diukur melalui kemampuan peserta didik dalam mengungkapkan kemampuan komunikasi matematisnya secara tertulis dalam permasalahan matematika. Dalam setiap permasalahan matematika, pengukuran kemampuan komunikasi secara tertulis dilakukan dengan indikator-indikator kemampuan komunikasi matematis.

Indikator komunikasi matematis menurut NCTM (1989) dapat dilihat dari: (1) Kemampuan mengekspresikan ide-ide matematis melalui, tulisan, dan mendemonstrasikannya serta menggambarkannya secara visual; (2) Kemampuan memahami, menginterpretasikan, dan mengevaluasi ide-ide matematis baik secara lisan, tulisan, maupun dalam bentuk visual lainnya; (3) Kemampuan dalam menggunakan istilahistilah, notasi-notasi matematika dan struktur-strukturnya untuk menyejikan ideide, menggambarkan hubungan- hubungan dengan model-model situasi.

Dalam penelitian ini kemampuan komunikasi peserta didik sekolah dasar yang diukur, yaitu 1) Kemampuan mengekspresikan ide-ide matematis, tulisan, (2) Kemampuan memahami, dan mengevaluasi ide-ide matematis secara tulisan. 
Pendekatan Saintifik merupakan pendekatan pembelajaran ilmiah menekankan pada pentingnya kolaborasi dan kerja sama di antara peserta didik. Pendekatan saintifik merupakan salah satu pendekatan pembelajaran ilmiah. Majid (2014: 193) mengungkapkan bahwa penerapan pendekatan saintifik bertujuan untuk pemahaman kepada peserta didik dalam mengenal, memahami berbagai materi menggunakan pendekatan ilmiah, bahwa informasi bisa berasal dari mana saja, kapan saja, tidak bergantung pada informasi searah dari guru.

Pendekatan saintifik merupakan pendekatan yang berpusat kepada peserta didik. Majid (2014: 211) menyebutkan bahwa pendekatan saintifik dalam pembelajaran meliputi mengamati, menanya, mencoba, mengolah, menyajikan, menyimpulkan, dan mencipta. Pendapat tersebut sejalan dengan yang diungkapkan oleh Daryanto (2014: 59-80), yaitu:

Pertama, mengamati. Metode mengamati mengutamakan kebermaknaan proses pembelajaran. Metode ini memiliki keunggulan tertentu, seperti menyajikan media obyek secara nyata, peserta didik senang dan tertantang, dan mudah dalam pelaksanaan. Seperti yang diungkapkan oleh Daryanto (2014: 60) bahwa metode mengamati sangat bermanfaat bagi pemenuhan rasa ingin tahu peserta didik, sehingga proses pembelajaran memiliki kebermaknaan yang tinggi.

Kedua, menanya. Guru membuka kesempatan kepada peserta didik secara luas untuk bertanya mengenai apa yang sudah dilihat, disimak, atau dibaca. Daryanto (2014: 65) mengungkapkan bahwa guru yang efektif mampu menginspirasi peserta didik untuk meningkatkan dan mengembangkan ranah sikap, keterampilan, dan pengetahuannya. Pada saat guru bertanya, pada saat itu pula dia membimbing atau memandu peserta didik belajar dengan baik.

Ketiga, menalar. Kegiatan menalar menurut Permendikbud Nomor 81a Tahun
2013 (dalam Daryanto, 2014: 70) adalah memproses informasi yang sudah dikumpulkan baik terbatas dari hasil kegiatan mengumpulkan atau eksperimen maupun hasil dan kegiatan mengumpulkan informasi. Kegiatan ini dilakukan untuk menemukan keterkaitan satu informasi dengan informasi lainnya, menemukan pola dari keterkaitan informasi tersebut.

Keempat, mencoba. Hasil belajar yang nyata atau otentik akan didapat bila peserta didik mencoba atau melakukan percobaan. Daryanto (2014: 78) mengungkapkan bahwa aplikasi mencoba atau eksperimen dimaksudkan untuk mengembangkan berbagai ranah tujuan belajar, yaitu sikap, keterampilan, dan pengetahuan.

Kelima, mengkomunikasikan. Guru diharapkan memberi kesempatan kepada peserta didik untuk mengkomunikasikan apa yang telah mereka pelajari dalam pendekatan saintifik. Daryanto (2014: 80) mengungkapkan bahwa kegiatan mengkomunikasikan dilakukan melalui menuliskan atau menceritakan apa yang ditemukan dalam kegiatan mencari informasi, mengasosiasikan dan menemukan pola.

Pendapat ahli tersbut dapat disimpulkan bahwa langkah-langkah dalam pendekatan saintifik adalah $5 \mathrm{M}$ yaitu, mengamati, menanya, menalar, mencoba, dan mengkomunikasikan. Tahapan-tahapan pendekatan saintifik memiliki tujuan agar peserta didik dapat berpartisipasi dan terlibat aktif selama pembelajaran.

\section{METODOLOGI PENELITIAN}

Berdasarkan permasalahan penelitian yang telah dipaparkan, maka penelitian yang dilaksanakan ini dapat digolongkan sebagai penelitian tindakan kelas (action research), dengan menggunakan metode deskriptif kualitatif dan rancangan penelitian tindakan. Menurut Suharsimi (2008: 104), penelitian tindakan kelas adalah suatu penelitian yang akar masalahnya muncul di kelas, dan dirasakan langsung oleh guru yang 
bersangkutan. Sedangkan menurut Kunandar (2008: 44) penelitian tindakan kelas adalah penelitian yang dilakukan oleh guru yang sekaligus sebagai peneliti di kelasnya atau bersama-sama dengan orang lain (kolaborasi).

Penelitian dilakukan dengan jalan merancang, melaksanakan dan merefleksikan tindakan secara kolaboratif dan partisipatif yang bertujuan untuk memperbaiki proses pembelajaran di kelas melalui suatu tindakan dalam suatu siklus.

Pendekatan yang digunakan peneliti adalah pendekatan kualitatif dan kuantitatif karena pendekatan kualitatif merupakan: 1) data yang akan dipaparkan berupa kata-kata dan bersifat deskriptif, 2) dilakukan pada latar alami, 3) peneliti sebagai instrumen utama, dan 4) penekanan penelitian pada hasil dan proses. Sedangkan alasan penggunaan pendekatan kuantitatif adalah karena berhubungan dengan hasil belajar peserta didik yang berupa angka-angka dan analisisnya menggunakan statistic.

Penelitian ini dilakukan di kelas V SD Negeri 016 Bangkinang Kota. Peneliti memilih SD Negeri 016 Bangkinang Kota sebagai tempat penelitian karena, di sekolah tersebut belum pernah dilakukan penelitian matematika yang berkaitan dengan kemampuan komunikasi matematik dan belum pernah diimplementasikan pendekatan saintifik dalam pembelajarannya. Dan alasan lainnya adalah peneliti melihat bahwa kemampuan komunikasi matematik peserta didik masih tergolong rendah. Penelitian tindakan kelas ini dilakukan pada peserta didik kelas $\mathrm{V}$ semester II SDN 016 Bangkinang Kota. Jumlah peserta didiknya yaitu 32 orang, terdiri dari 20 orang perempuan dan 12 orang laki-laki.

Alur penelitian PTK yang dilakukan mengikuti alur yang dikemukakan oleh Kemmis dan Taggart (dalam Ritawati dan Yetti, 2008: 69) menyatakan "Proses penelitian tindakan kelas merupakan daur ulang atau siklus yang dimulai dari aspek mengembangkan perencanaan, melakukan tindakan sesuai rencana, melakukan observasi terhadap perencanaan tindakan dan melakukan refleksi yang berupa perenungan terhadap perencanaan kegiatan, tindakan dan hasil yang diperoleh".

Kegiatan penelitian dimulai dengan refleksi awal untuk melakukan tindakan pendahuluan tentang kondisi objektif yang terjadi di lapangan. Langkah ini dilakukan untuk memperoleh informasi tentang kesulitan-kesulitan yang harus segera diatasi. Setelah itu dilakukan kegiatan perencanaan, pelaksanaan tindakan, pengamatan dan refleksi. Kegiatan ini mungkin diikuti perencanaan ulang, tindakan ulang, pengamatan ulang dan refleksi ulang.

Sebelum melakukan penelitian, peneliti melakukan studi pendahuluan berupa observasi awal terhadap kemampuan komunikasi matematis di kelas V SD semester II. Hal ini dilakukan untuk mengetahui permasalahan yang dihadapi guru dan peserta didik berkaitan dengan kemampuan komunikasi matematik. Selanjutnya, dilakukan tahap-tahap yang akan dilakukan dalam penelitian ini mencakup: a) tahap perencanaan; b) tahap pelaksanaan; c) tahap pengamatan; d) tahap refleksi.

Teknik pengumpulan data ini meliputi a) observasi, b) tes, dan c) dokumentasi. Observasi dilakukan untuk mengamati latar belakang tempat berlangsungnya pembelajaran dengan menerapkan pendekatan saintifik. Dengan berpedoman kepada lembaran observasi, peneliti juga mengamati apa yang terjadi selama proses pembelajaran. Tes berfungsi untuk melihat hasil kemampuan komunikasi matematik peserta didik setelah diberi tindakan berupa pembelajaran dengan pendekatan saintifik. Dokumentasi berupa pengambilan foto dilakukan oleh teman sejawat peneliti saat proses pembelajaran berlangsung. Dokumentasi ini bertujuan untuk melihat kegiatan yang dilakukan guru dan peserta didik terutama pada kegiatan-kegiatan pokok dari pendekatan saintifik. Dokumentasi 
digunakan untuk mengabadikan kegiatankegiatan penting dari pendekatan saintifik sehingga dapat melengkapi data lapangan yang terjadi bila ada hal yang terlepas dari pengamatan peneliti.

Ada beberapa instrumen atau alat pengumpul data dalam penelitian ini yaitu: a) Lembar observasi. Lembar observasi digunakan untuk mengetahui kegiatan belajar peserta didik selama proses pendekatan saintifik berlangsung, b) Lembar Tes.Tes berfungsi untuk melihat hasik kemampuan komunikasi matematik peserta didik setelah diberi tindakan berupa pembelajaran dengan pendekatan saintifik, dan c) Alat perekam/kamera Alat perekam digunakan untuk mengambil gambar sebagai dokumentasi nantinya bertujuan untuk melihat kegiatan yang dilakukan guru dan peserta didik terutama pada kegiatan-kegiatan pokok dari pendekatan saintifik. Data yang diperoleh dianalisis dengan menggunakan analisis data kualitatif dan kuantitatif. Model data kualitatif oleh Miles dan Huberman (dalam Akhmad, 2009: 8) yakni analisa data dimulai dengan menelaah sejak pengumpulan data sampai seluruh data terkumpul. Tahap analisis dapat diuraikan sebagai berikut:

Pertama, menelaah data yang telah terkumpul baik melalui observasi, pencatatan, perekaman, maupun dokumentasi. Kegiatan penelaahan ini diawali dengan transkripsi data hasil pengamatan, kemudian menganalisis, mensintesis, memaknai, dan menyimpulkan. Penelaahan ini dilakukan secara menyeluruh sejak awal data dikumpulkan hingga semua data terkumpul.

Kedua, reduksi data, meliputi pengkategorian dan pengklasifikasian. Semua data yang telah terkumpul diseleksi dan dikelompok-kelompokkan sesuai dengan masalah penelitian. Data yang telah diklasifikasikan tersebut kemudian diseleksi mana yang relevan dan mana yang tidak relevan. Data yang relevan selanjutnya dianalisis dan data yang tidak relevan dibuang.

Ketiga, menyajikan data dilakukan dengan cara mengorganisasikan informasi yang telah direduksi. Data tersebut dipaparkan menurut jenisnya sesuai dengan masalah penelitian.

Keempat, menyimpulkan hasil penelitian. Kegiatan penyimpulan hasil penelitian dilakukan dengan menafsirkan makna sesuatu fenomena yang terjadi selama tindakan berlangsung.

\section{HASIL PENELITIAN DAN PEMBAHASAN}

Pelaksanaan pembelajaran dengan menggunakan pendekatan saintik pada siklus I ini masih ada beberapa deskriptor pembelajaaran yang belum terlaksana dengan baik.

Pada pelaksanaan tahap menanya, belum semua peserta didik yang mau memberikan pertanyaan. Pada tahap menalar juga demikian, belum semua peserta didik yang mau menyampaikan hasil pemikirannya. Namun ketika tahap menyimpulkan hasil peserta didik yang diberikan amanah untuk menyampaikan hasil diskusi kelompok mampu untuk menyampaikannya dengan baik.

Berdasarkan refleksi guru memberikan waktu untuk mencatat yang telah dipelajari. Dan memberikan kesempatan kepada peserta didik untuk menanyakan bagian materi yang tidak dimengerti peserta didik. Pada kegiatan ini peserta didik sudah serius dalam memberikan pertanyaan atau mengajukan pertanyaan. Diakhir pembelajaran, peserta didik menyimpulkan pembelajaran dengan bimbingan guru. Pada kegiatan ini peserta didik sudah antusias dalam menyimpulkan pembelajaran.

Berdasarkan hasil pengamatan yang telah dilakukan pada pertemuan I pelaksanaan dapat dilihat dari aspek guru dan peserta didik dimana pada aspek guru didapatkan persentase 78,56 (termasuk kategori baik) dan aspek peserta didik 
didapatkan persentase 67,28 (termasuk kategori cukup). Pada pertemuan 2 aspek guru didapatkan persentase 89,54 dan aspek peserta didik $83,53 \%$. Hal ini menunjukkan bahwa pada pelaksanaan siklus 1 belum terlaksana sesuai dengan langkah-langkah pendekatan saintifik. Berdasarkan diskusi peneliti dengan observer penyebab belum terlaksananya pendekatan saintifik pada siklus I adalah guru kurang meningkatkan pemahaman peserta didik terhadap materi sebelumnya (apersepsi), kurang memberikan motivasi, pengkondisian kelas kurang, sedangkan dari peserta didik, kurang aktifnya peserta didik dalam proses pembelajaran karena peserta didik baru mempelajari materi ini, beberapa peserta didik tidak serius mendengarkan penjelasan guru,dan ketika peserta didik diminta untuk menjawab pertanyaan guru namun hanya beberapa peserta didik yang dapat menjawab pertanyaan dengan benar, dan sewaktu kegiatan kelompok ada beberapa peserta didik yang tidak terlibat secara aktif .

Berdasarkan hasil penelitian dan analisis data pada siklus I pertemuan 1 diketahui bahwa persentase nilai rata-rata kognitif peserta didik adalah 61,23\% , dimana peserta didik yang tuntas hanya 18 orang dan yang tidak tuntas ada 14 orang peserta didik. Persentase nilai rata-rata afektif peserta didik $71 \%$ dan psikomotor peserta didik adalah $70,11 \%$. Hal ini menujukkan bahwa tes yang diberikan guru berupa soal pilihan dalam menentukan jaring-jaring balok masih tergolong rendah. Pada pertemuan 2 diketahui bahwa persentase nilai rata-rata kognitif peserta didik adalah $62,54 \%$, dimana yang tuntas ada 20 orang peserta didik, dan yang tidak tuntas 12 orang peserta didik. Persentase nilai rata-rata afektif peserta didik $78 \%$ dan psikomotor peserta didik adalah $78,2 \%$. Hal ini menujukkan bahwa tes yang diberikan guru berupa soal kemampuan komunikasi matematik masih tergolong rendah. Sedangkan pada aspek afektif dan psikomotor peserta didik telah menujukkan peningkatan dengan menggunakan pendekatan saintifik.

Berdasarkan hasil pengamatan siklus I yang diperoleh, maka direncanakan untuk melakukan siklus II. Peneliti harus meningkatkan pembelajaran dan pengorganisasian waktu dengan tetap memperhatikan perbedaaan yang ada pada setiap peserta didik karena masing-masing individu memiliki karakteristik dan potensi yang berbeda.

Pelaksanaan pembelajaran menerapkan pendekatan saintifik pada siklus II sudah berlangsung dengan sangat baik. Pada langkah menanya, pertanyaan dan kegiatan yang diberikan guru sudah mengaktifkan pengetahuan peserta didik.

Pada pelaksanaan pembelajaran siklus II ini pelaksanaan pembelajaran sudah menujukkan peningkatan yang sangat baik. Berdasarkan hasil pengamatan yang telah dilakukan pada pertemuan 1 pelaksanaan dapat dilihat dari aspek guru dan peserta didik dimana pada aspek guru didapatkan persentase 97,20 (termasuk kategori sangat baik) dan aspek peserta didik didapatkan persentase $97 \%$ (termasuk kategori sangat baik). Pada pertemuan 2 aspek guru didapatkan persentase 97,54\%, dan aspek peserta didik 98,65\%. Hal ini menunjukkan bahwa pada pelaksanaan siklus II sudah terlaksana dengan baik sesuai dengan langkah-langkah pendekatan saintifik. Berdasarkan diskusi peneliti dengan observer sudah terlaksananya pendekatan saintik pada siklus II adalah guru sudah memberikan motivasi, pengkondisian kelas sudah sangat baik, sedangkan dari peserta didik,sudah aktifnya peserta didik dalam proses pembelajaran karena peserta didik sudah mempelajari materi ini beberapa kali, hanya satu sampai tiga orang peserta didik yang tidak serius mendengarkan penjelasan guru,dan ketika peserta didik diminta untuk menjawab pertanyaan guru hampir semua peserta didik yang dapat menjawab pertanyaan dengan benar, dan sewaktu kegiatan kelompok sudah banyak peserta didik yang terlihat aktif. 
Selain itu pembagian kelompok yang sudah dikurangi sangat menunjang guru dalam menguasai kelas dalam pembelajaran. Dari hasil tes yang diperoleh sudah terlihat peserta didik memahami materi dengan baik dan memiliki kemampuan komunikasi matematik yang meningkat. Hal ini dikarenakan peserta didik sudah mulai menujukkan perhatian dan keseriusan dalam pelaksanaan pembelajaran.

Berdasarkan hasil penelitian dan analisis data pada siklus II pertemuan 1 diketahui bahwa persentase nilai rata-rata kognitif peserta didik adalah 92,61\% ,persentase nilai rata-rata afektif peserta didik $83,51 \%$ dan psikomotor peserta didik adalah $81,4 \%$. Hal ini menujukkan bahwa tes yang diberikan guru berupa soal esai untuk mengukur kemampuan komunikasi matematik peserta didik tergolong tinggi. Pada pertemuan 2 diketahui bahwa persentase nilai rata-rata kognitif peserta didik adalah $94,65 \%$, persentase nilai ratarata afektif peserta didik $91 \%$ dan psikomotor peserta didik adalah $87,72 \%$. Hal ini menujukkan bahwa tes yang diberikan guru berupa soal esai untuk mengukur kemampuan komunikasi matematik tergolong tinggi. Sedangkan pada aspek afektif dan psikomotor peserta didik telah menujukkan peningkatan menggunakan pendekatan saintik. Berdasarkan pembahasan di atas maka pelaksanaan siklus II telah terlaksana dengan sangat baik dan guru telah berhasil menerapkan pendekatan saintik pada pembelajaran matematika SD materi geometri.

\section{KESIMPULAN}

Berdasarkan hasil penelitian dan bahasan maka peneliti dapat menyimpulkan sebagai berikut :

1. Pelaksanaan pembelajaran dengan pendekatan saintifik dilaksanakan 2 siklus. Masing-masing siklus dilaksanakan 2 pertemuan. Pembelajaran dengan pendekatan saintifik mempunyai 5 langkah yaitu 1) mengamati, 2) menanya, 3) menalar, 4) mencoba 5) mengkomunikasikan. Keseluruhan langkah pembelajaran ini terlihat pada kegiatan awal, inti, dan akhir.

2. Peningkatan kemampuan komunikasi matematik dapat dilihat dari presentase hasil belajar peserta didik yang dilihat pada aspek kognitif, afektif dan aspek psikomotor dengan dngan menerrapkan pendekatan CTL

\section{DAFTAR PUSTAKA}

Anonim. (2005). The Ontario Curriculum Mathematics. Ontario: Ministry Education's.

Bistari.BsY. (2010). Pengembangan Kemamdirian belajar berbasis nilai untuk meningkatkan komunikasi matematika. Jurnal Pendidikan Matematika dan IPA Vol.1. No.1 Januari 2010:11-23.

Brener, M.E. (1998). Development of Mathematical Communication in Problem Solving Groups by Language Minirity Students. Bilingual Research Journal,22;2,3 \& 4 Spring, Summer,\& Fall 1998

Daryanto, (2014). Pembelajran Tematik, Terpadu, Terintegrasi (Kurikulum 2013). Jogjakarta: Gava Media

Kunandar. (2008). Langkah Mudah Penelitian Tindakan Kelas sebagai Pengembangan Profesi Guru. Jakarta : PT Raja Grafindo Persada Indonesia

Majid, Abdul. (2014). Pembelajaran Tematik Terpadu. Bandung: PT Remaja Rosdakarya

National Council of Teachers of Mathematics. (1989). Curriculum 
and Evaluation Standar for School Mathematics. Reston VA : The National Council of Teachers of Matematics Inc.

Qahar, Abd. (2011). Pengembangan Instrumen Komunikasi Matematis Untuk Siswa SMP. LSM IX Lomba dan Seminar Matematika. Hima Matematika

Rahmawati, F. (2013). Pengaruh Pendekatan Pendidikan Realistik Matematika dalam Meningkatkan Kemampuan Komunikasi Matematis Siswa Sekolah Dasar. Makalah pada Seminar Semirata 2013 Fakultas MIPA Universitas Lampung.

Suharsimi Arikunto, Suhardjono dan Supardi. (2008). Penelitian Tindakan Kelas.

Yuniawatika. (2011). Penerapan Pembelajaran Matematika Dengan Strategi REACT Untuk Meningkatkan Kemampuan Koneksi dan Representasi Matematika Siswa Sekolah Dasar. [Tesis, 2011, Universitas Pendidikan Indonesia, Tidak diterbitkan]. 